\title{
Ehretia longiflora (Boraginaceae): A new record for India from Andaman \& Nicobar Islands
}

\author{
Joju P. Alappatt* \\ Department of Environment and Forests, Forest Training Institute, Wimberlygunj, \\ Andaman and Nicobar Islands - 744 206, India. \\ *Email: jojualappatt@yahoo.com
}

\begin{abstract}
Ehretia longiflora Champ. ex Benth. is first reported from the Andaman \& Nicobar Islands to the flora of India. A brief description with photographs is provided for easy identification.
\end{abstract}

Keywords: Andaman \& Nicobar Islands, Boraginaceae, Ehretia longiflora, India, New Record.

\section{Introduction}

Ehretia P. Browne (Boraginaceae), the largest genus of the subfamily Ehretioideae comprises about 50 species, distributed mostly in Africa, South Asia, North America and the Caribbean islands (Zhu et al., 1995). Four species of Ehretia have been recorded in Andaman and Nicobar Islands so far (Pandey \& Diwakar, 2008; Murugan et al., 2016). Among them, Ehretia dichotoma Blume and E. timorensis Decne. occur in Andaman Islands only while E. laevis Roxb. has been reported from both Andaman and Nicobar group of Islands. Ehretia microphylla Lam. is a cultivated species.

During floristic explorations in South Andaman Island, a few specimens belonging to the genus Ehretia were collected. Based on critical study and review of literature (Johnston, 1951; Zhu et al., 1995; Mill, 1996; Hsiao et al., 1998), the specimens were identified as Ehretia longiflora Champ. ex Benth. A thorough scrutiny of literature (Clarke, 1883; Sinha, 1999; Pandey \& Diwakar, 2008; Murugan et al., 2016) revealed that this species was hitherto unrecorded from Andaman \& Nicobar Islands and mainland India. In the present treatment the species is reported as new addition to the flora of India. A brief description along with photographs is provided to facilitate easy recognition of this species in the field.

\section{Taxonomy}

Ehretia longiflora Champ. ex Benth., Hooker's J. Bot. Kew Gard. Misc. 5: 58. 1853; Gagnep. \& Cour. in Lecomte, Fl. Indo-Chine 4: 210. 1914; Kaneh., Form.
Trees Rev. ed. 637.f. 593. 1936; Hou, Taiwania 1: 203. 1950; H.L. Li, Woody Fl. Taiwan 812. 1963; Z.Y. Zhu, Riedl \& Kamelin in Z.Y. Wu \& P.H. Raven, Fl. China 16: 335. 1995; J.Y. Hsiao \& H.Y. Liu in T.C. Huang, Fl. Taiwan ed. 2, 4: 395. 1998. E. glaucescens Hayata, Icon. Pl. Form. 3: 153. 1913.

Fig. 1.

Trees, upto $10 \mathrm{~m}$ tall; bark dark gray to dark brown, scaly; young branches brown, lenticellate, branchlets greenish, glabrous. Leaves elliptic to oblongoblanceolate, 3-16 $\times 3-7 \mathrm{~cm}$, subcoriaceous, glabrous, base cuneate, margins entire, apex abruptly acute to acuminate or short-caudate, greenish and shining above; lateral veins 4-7 pairs; petioles $1-3 \mathrm{~cm}$ long. Cymes terminal on lateral branches, flat topped, densely flowered, 3-6 cm wide; peduncles $2-5 \mathrm{~cm}$ long. Flowers sessile or on short pedicels, c. $1 \mathrm{~cm}$ long, $0.5 \mathrm{~cm}$ across, fragrant. Calyx $2-2.5 \mathrm{~mm}$, hairy; lobes ovate, c. $1.5 \mathrm{~mm}$ long, ciliate along margins. Corolla tubular-campanulate, creamy to greenish white, 10-12 mm long, corolla tube 9-10 mm long, base $c .1 .5 \mathrm{~mm}$ wide, slightly hairy, glabrous inside, throat 3-4 mm wide; lobes 5, ovate to elliptic-ovate, $c$. $2 \mathrm{~mm}$, shorter than tube, spreading, soon becoming reflexed. Stamens 5, inserted $3.5-5 \mathrm{~mm}$ above the base of corolla tube; filaments filiform, $8-9 \mathrm{~mm}$ long, anthers $c .1 \mathrm{~mm}$ long. Ovary glabrous, c. $1 \times 1 \mathrm{~mm}$; style 10-11 mm, 2-cleft at apex, branches $c .1 \mathrm{~mm}$ long, stigma capitate; ovules 4 . Drupes glabrous, green when young, pale yellow to orange red when matured, 9-11 mm in diam.; endocarp divided at maturity into four 1-seeded pyrenes.

Flowering \& fruiting: March-June. 

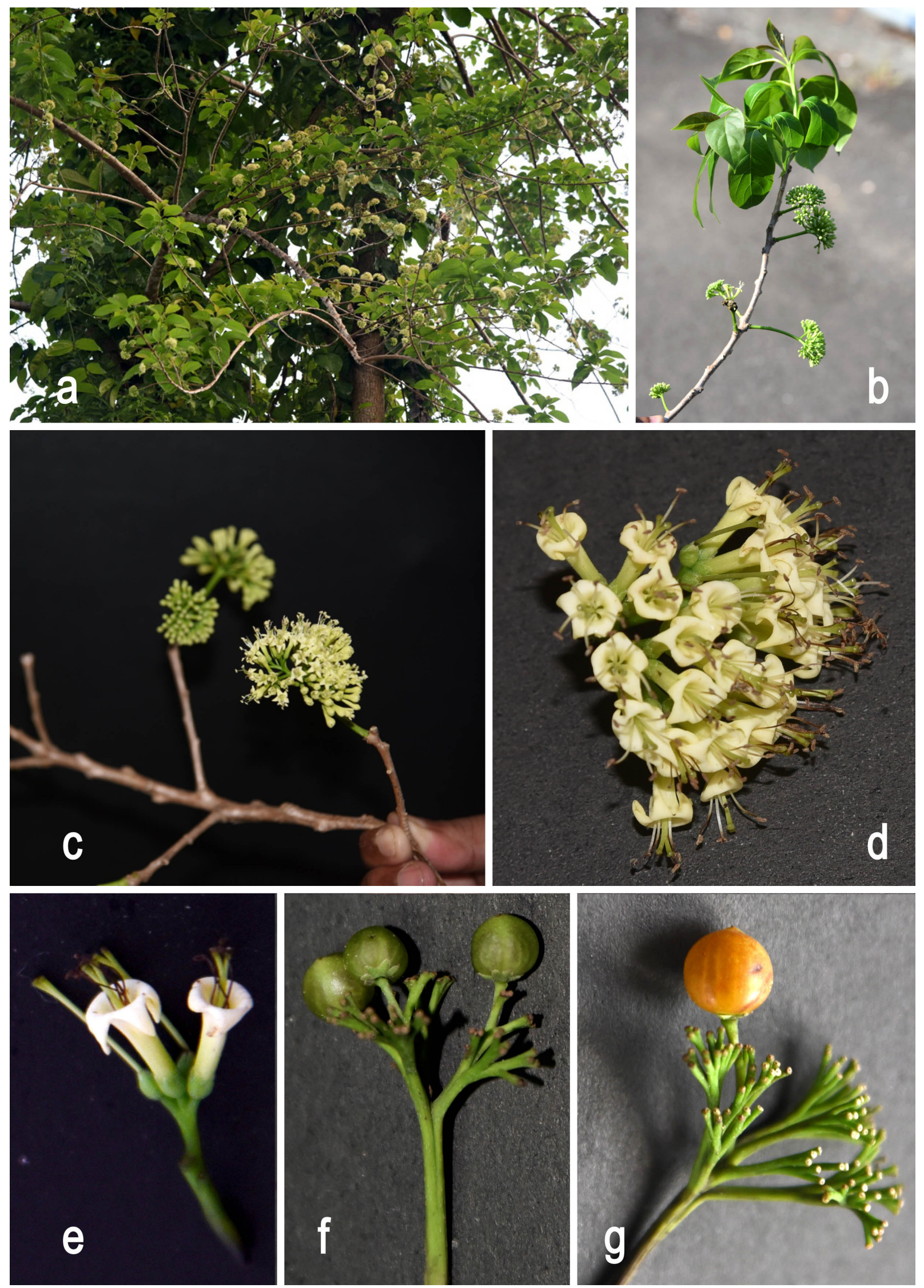

Fig. 1. Ehretia Iongiflora Champ. ex Benth.: a. Habit; b. Flowering branch; c. Inflorescence; d \& e. Flowers-close up views; $\mathbf{f} \&$ g. Fruitsmatured \& ripened (Photos by Joju P. Alappatt). 
Habitat: Rare in inland evergreen forests growing in association with Bombax insigne Wall., Cryppteronia paniculata Blume, Elaeocarpus tectorius (Lour.) Poir., Ficus callosa Willd., F. hispida L.f., F. nervosa B. Heyne ex Roth, Heteropanax fragrans (Roxb.) Seem., Pterocymbium tinctorium Merr. and Tetrameles nudiflora R.Br. at an elevation of about $20-30 \mathrm{~m}$ from the sea level.

Distribution: China, Hong Kong, Taiwan, Vietnam and now in India.

Specimens examined: INDIA, Andaman \& Nicobar Islands, South Andaman Island, Mt. Harriet Hill Ranges, near Hope Town, 31.03.2017, Joju P. Alappatt 1456 (Herbarium, Forest Training Institute, Wimberlygunj); Hope Town, 07.03.2018, Joju P. Alappatt 1519 (PBL). CHINA, Little Hong Kong, February 1958, C.Wilford 355 (K000998021, digital image!), Hong Kong, s.d., J.G. Champion s.n. (K000998018, digital image!); Ibid., 1854, G. Bentham 146 (K000998019, digital image!).

Notes: Ehretia longiflora belongs to a group of very closely related but geographically isolated species in which the other members are E. dunniana H.Lev. (South China), E. javanica Blume (Indonesia, Malesia and Thailand) and E. wallichiana Hook.f. \& Thomson ex Gamble (North East India, Nepal, Burma and Bhutan). In E. dunniana secondary and tertiary veins are more evident in the leaf lamina. Young twigs, inflorescence and calyx are densely and minutely pubescent and corolla tube is less than $10 \mathrm{~mm}$ long. E. javanica has more rounded, more evidently veined, broadly elliptic leaves. $E$. wallichiana has thinner much more evidently veined leaves and flowers with a larger calyx (3.0-4.5 mm), shorter corolla tube (5-6 mm) and longer lobes (3.0$4.5 \mathrm{~mm}$ ) and larger anthers $(1.7 \mathrm{~mm})$.

Key to the species of Ehretia in Andaman \& Nicobar Islands

1. Cymes 1-3-flowered; leaves small (<3.5 cm long) with few dentations at apex ............... E. microphylla

1. Cymes many flowered; leaves large $(>5 \mathrm{~cm}$ long) margin serrate or entire ... 2

2. Corolla tube twice as long as corolla lobes. E. longiflora

2. Corolla tube shorter than or as long as corolla lobes 3

3. Inflorescence produced on new shoots bearing well developed leaves. E. dichotoma

3. Inflorescence produced on roughened/verrucose shoots of previous season before new leaves......... 4
4. Leaves smaller, ovate to lanceolate, shortly acuminate E. laevis

4. Leaves larger, broadly oblong to oblanceolate, more acuminate. E. timorensis

\section{Acknowledgements}

The author is grateful to Shri Tarun Coomar IFS, PCCF, Department of Environment \& Forests, Andaman \& Nicobar Islands and Dr. Lal Ji Singh Botanical Survey of India, Port Blair for providing facilities and support.

\section{Literature Cited}

Clarke, C.B. 1883. Boragineae. In: Hooker, J.D. (ed.), The Flora of British India. Vol. 4. L. Reeve \& Co. Ltd., London. pp. 134-179.

Hsiao, J.Y. \& H.Y. Liu 1998. Boraginaceae. In: Huang, T.C. (ed.), Flora of Taiwan, Secondedition. pp. 582-646.

Johnston, I.M. 1951. Studies in the Boraginaceae, XX. Representatives of three subfamilies in Eastern Asia. J. Arnold Arbor. 32: 1-26, 99-122.

Mill, R.R. 1996. Notes relating to the Flora of Bhutan: XXXV. Boraginaceae, III. Ehretia wallichiana: a tangle disentangled. Edinburgh $\mathrm{J}$. Bot. 53(2): 247-270.

Murugan C., Prabhu S., Sathiyaseelan R. \& R.P. Pandey, 2016. A checklist of plants of Andaman and Nicobar Islands. ENVIS Centre on Floral Diversity, Botanical Survey of India, Kolkata. Available from: http:/www.bsienvis.nic.in/ database/Checklist-of-Andaman-Nicobarislands 24427.aspx (accessed 28.10.2017)

Pandey, R.P. \& P.G. Diwakar 2008. An integrated checklist flora of Andaman and Nicobar Islands, India. J. Econ. Taxon. Bot. 32(2): 403-500.

Sinha, B.K. 1999. Boraginaceae. In: Hajra, P.K. \& P.S.N. Rao (eds.), Flora of Great Nicobar Island. Botanical Survey of India, Kolkata. pp. 315-317.

Zhu, G., Riedl, H. \& R.V. Kamelin. 1995. Boraginaceae. In: Wu, Z.Y. \& P.H. Raven (eds.), Flora of China. Vol. 16 (Gentianaceae through Boraginaceae). Science Press, Beijing and Missouri Botanical Garden Press, St. Louis. 479 pp.

Received: 30.04 .2018

Revised and Accepted: 17.12.2018 